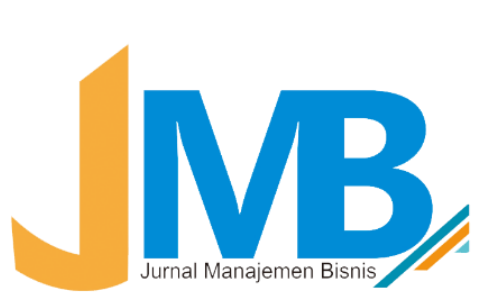

\title{
THE EFFECT OF ATTITUDE, SUBJECTIVE NORMS AND CONTROL OF BEHAVIOR TOWARDS INTENTION IN SHARE INVESTMENT
}

\author{
Erna Retna Rahadjeng ${ }^{1}$, Yulist Rima Fiandari ${ }^{2}$ \\ ${ }^{1}$ Universitas Muhammadiyah Malang, Malang, Indonesia \\ ${ }^{2}$ Universitas Muhammadiyah Malang, Malang, Indonesia \\ Corresponding Author's Email:yulist_rima@umm.ac.id
}

Received:19-07-2020 | Revision: 20-09-2020 | Accepted:28-10-2020

To cite this document:

Rahadjeng, Erna Retna, Fiandari, Yulist Rima (2020) "The Effect of Attitude, Subjective Norms and Control of Behavior Towards Intention In Share Investment", Manajemen Bisnis, Vol. 10, No. 02, pp.17-

26, http://ejournal.umm.ac.id/index.php/jmb/article/view/13616

\section{ABSTRACT}

The development of the stock market has been dominated by individual. The decisionmaking process in investment actions is influenced by various individual characteristics and systematic factors are important elements that have an important influence on investors' financial decision making. Stock purchases can be influenced by attitudes, subjective norms and biases from past experiences. Stock investment is starting to be of interest to scholars. This study aims to determine and analyze the effect of attitudes, subjective norms and behavioral control on investment intentions in the capital market. The population that will be used as the research object is scholars in Malang, who have already been familiar with finance courses. The sampling method used was purposive sampling, namely determining the sample according to the research objectives. Data analysis is used to determine the effect of independent variables on the dependent variable, which is analyzed using path analysis with PLS. The result show that attitudes, subjective norms and behavioral control have an influence on the intention to invest in shares investment.

Keywords: attitude, subjective norm, behavior control and intention to invest in stocks

\section{INTRODUCTION}

Investment enthusiasts in the Indonesian capital market have increased (Hati and Harefa, 2019). Stock investment is starting to be of interest to scholars. The decisionmaking process in investing is influenced by various individual characteristics and systematic factors as important elements that have an important influence on investors' financial decision making(Agnew, 2006). Research on the factors that influence the interest in buying shares in scholars has not been widely studied, so it is necessary to further know the factors that influence stock decision making, especially among scholars. Scholars as the younger generation who also play a role in the development of 
economic activities in the future, so it is necessary to know the interest of scholars in purchasing shares. Research Raut et al., (2018) revealed that stock purchases can be influenced by attitudes, subjective norms, behavioral control, and past experience bias. The act of investing is also related to the interest in investing. The study for taking action begins with the Reason for Action Theory. The Reason for Action Theory put forward by Fishbein and Ajzen (Ajzen, 1991). The foundation in decision making from the aspect of behavior is important to research. The Reason for Action Theory will show the factors that influence the purchase of shares. Economic anomalies in the market also affect company performance. The results obtained show mixed results. Some company performance is successful in accordance with the target, but some are not in accordance with the company's target. These achievements provide information for investors to act.

The actions that have been taken will form the basis for further action (Hidayat et al., 2019). The level of return obtained compared to the risk received by investors becomes a consideration in investing. Investing in stocks at a high level of risk provides an opportunity for investors to obtain a high rate of return as well. Investors who do not like high risk can choose stocks with a low level of risk (Christanti et al., 2011). The financial behavior paradigm is aimed at seeing another side to be known(Tuyon and Ahmad, 2016). This research is expected to enrich the repertoire of financial behavior so that it will provide a reference for companies in understanding investor behavior, and to what extent attitudes, subjective norms and behavioral control affect the intention to invest in stocks. Based on the formulation of the problems described above, the objectives of this study are nalyzing the effect of attitude, subjective norms and individual behavior on intention to invest in stocks.

\section{LITERATURE REVIEW}

Investor behavior in making stock investment decisions is projected with the intention of individual investors in choosing stocks. The intention of individual investors is reflected in the estimated stock returns that are calculated using a variety of information. The intention itself is an intention to behave that grows because of the information that triggers a person's motivation to make a decision. Ajzen (1991) reveals a Theory of Planned Behavior (a theory of reasoned action), this theory is based on the assumption that humans are rational beings and use information that is possible for them systematically. Theory of Planned Behavior (TPB) is an extension of the theory of reasoned action (TRA). Theory of reasoned action explains that a person's intention towards behavior is formed by two main factors, namely attitude toward the behavior and subjective norm (Fishbein and Ajzen, 1975), while the TPB added one more factor, namely perceived behavioral control (Ajzen, 1991).

Theory of Planned Behavior was developed to predict behavior completely not under individual control. In this theory the most important determinant of a person's behavior is the intention to behave. The determinants of an individual's intention to display a behavior are attitudes to display that behavior, subjective norms, and perceptions of behavior control. This study develops previous studies regarding investors' 
intentions in choosing stocks. This study aims to determine the factors that influence the behavior of individual investors in choosing stocks, and also to determine whether relevant, reliable, and fairness accounting information is useful for investors in stock selection.

Ginting (2018) states that attitude is a person's positive or negative feelings towards a behavior or object. Attitude is a forming part of behavior (Lubis, 2010). Attitude has a role to direct action as a manifestation of the information one has on one's perception. Individuals will do something according to the attitude they have towards a behavior. Attitudes towards behavior that he considers positive will later be chosen by individuals to behave. An individual will do a certain behavior if his behavior can be accepted by people who are considered important in his life can accept what he will do (Ruby et al., 2019). According to Munandar (2014) subjective norms are the feelings or expectations of a person against the expectations of the people in his life regarding the behavior or not being done. This aspect is especially true for the perceived social pressure that comes from people who are important to someone (Sreen et al., 2018). Subjective norms areperception or one's view of other people's beliefs that will influence intention to perform or not perform the behavior under consideration (Jogiyanto, 2007).

The behavior of an individual can be completely controlled under the control of the individual. Behavioral control can be used to predict a person's intention to carry out an action (Johe \& Bhullar, 2016). Perceived behavioral control describes the perception of ease or difficulty in carrying out an action that reflects experiences experienced in the past (Paul et al., 2016). If you think that an action is easy to do without any significant obstacles, the individual will immediately manifest the intention to take an action or behavior to be realized (Ruby et al., 2019). Perceived behavioral control is related to the resources owned and the opportunity to do something (Tan and Teo, 2000).

Intention to invest in stock is the dependent variable which are connected directly by the dependent variable, namely attitude, subjective norms and perceived behavior control. The intention to invest in stocks is used to make expectations on the respondent for the intention to invest in stocks (Tan \& Teo, 2000). A positive attitude will encourage someone to invest in stocks. Subjective norms also have a contribution in purchasing stock, the more positive the subjective norms are formed, the greater the intention to buy stock. Intention to buy shares will be even stronger if a person believes he has the ability to purchase stock (Permatasari and Abdurrahman, 2016).

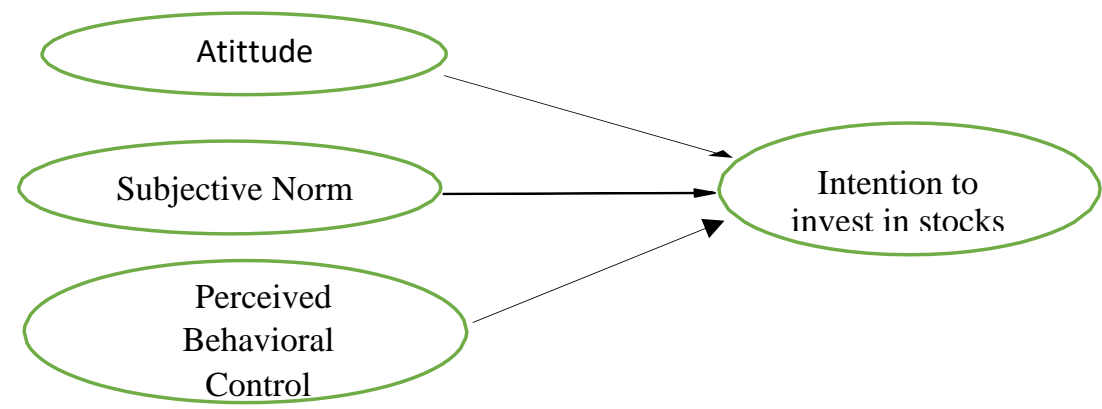

Figure 1. Conceptual Framework of the Intention to invest in stock 


\section{RESEARCH METHOD}

This type of research is an explanatory research type. Explanatory research is research that explains the causal relationship (cause-effect) between the variables that affect the hypothesis (Praharjo, 2020). The causal relationship in this study is to reveal the influence of attitudes, subjective norms, and behavioral control on investment intentions in scholars of the Faculty of Economics and Business, Muhammdiyah University Malang. Population is an area or generalized environment consisting of objects or subjects that have certain characteristics that are determined by the researcher to be studied and then draw conclusions. (Sugiyono, 2014). The population in this study were all FEB scholars of the Muhammadiyah University of Malang. The sample is part of a population group selected in a study (Widayat, 2004). The sample in this study is scholars who have taken TPAI (Portfolio Theory and Investment Analysis) courses. The consideration of selecting the sample is that scholars already have information and understand investment analysis and risks in the capital market.

The data collection technique used in this study was a survey method, by distributing a research instrument in the form of a questionnaire to respondents. The questionnaire is a data collection technique that is carried out by providing a set of questions or written statements to respondents to be answered (Sugiyono, 2014). This technique is carried out by distributing questionnaires to scholars of the Faculty of Economics and Business, University of Muhammadiyah Malang, which takes 2 weeks, detailing 5-10 questionnaires per day. Determination of the number of samples can be done 5 - 10 from the number of indicators (Ferdinand, 2014). The minimum sample size is $16 \times 5=80$. The questionnaire was distributed to 110 scholars and conducted online via google form. There are 10 questionnaires that have incomplete answers, so the number of questionnaires used to analyze this research is 100 questionnaires.

The data measurement technique used in this study is the Likert scale. The Likert scale is used to measure attitudes, opinions and perceptions of a person or group of people regarding social phenomena. Each question or statement is measured by a Likert scale which has five levels of preference answers, each of which is given a weighting of 1 to 5 with the breakdown of a score of $1=$ Strongly Disagree; score $2=$ Disagree; score $3=$ Neutral; score 4 = agree; score $5=$ totally agree. This research uses Warp PLS (Partial Least Square) due to simple assumptions. PLS is a method of analysis because not many assumptions are used (Ghozali, 2015; Junianto et al. 2020)

\section{RESULT AND DISCUSSION}

There are several criteria used in measuring the model before testing the hypothesis. Measurements taken include outer model and inner model measurements (Solimun et al., 2017). Outer model measurement is done by testing the validity and reliability of the research instrument. The tests carried out are: 1) convergent validity; 2) discriminant validity; and 3) composite reliability. Convergent validity evaluation is seen from the factor loading value obtained on the variable under study. The minimum loading factor value is 0.5 (Ghozali, 2015). The results showed the value of each factor loading factor 
The Effect of Attitude, Subjective Norms and Control of Behavior Towards Intention in Share Investment

above 0.5 on the variable attitude, subjective norms, perceived behavior control and intention. This shows that the value of convergent validity has been met.

Table 1. Value of Convergent Validity

\begin{tabular}{lccc}
\hline \multicolumn{1}{c}{ Variable } & Item & $\begin{array}{c}\text { Outer } \\
\text { Loading }\end{array}$ & Note \\
\hline Atittude (X1) & X1.1 & 0.809 & Valid \\
& X1.2 & 0.734 & Valid \\
& X1.3 & 0.668 & Valid \\
& X1.4 & 0.670 & Valid \\
Subjective Norm/ SN (X2) & X2.1 & 0.693 & Valid \\
& X2.3 & 0.833 & Valid \\
Percieved Behavioral Control/PBC & X2.4 & 0.694 & Valid \\
(X3) & X3.1 & 0.888 & Valid \\
& X3.3 & 0.877 & Valid \\
Intention to invest in stocks/ INT (Y) & Y1.1 & 0.810 & Valid \\
& Y1.2 & 0.841 & Valid \\
\hline
\end{tabular}

Discriminant validity can be seen from the comparison value between the loading value and the cross loading value. The loading indicator value on the variable is greater than the cross loading value, so it can be said that it has met the provisions of discriminant validity (Solimun et al., 2017). The comparison value data between the loading value and the cross loading value is presented in the Table. 2. The data in Table 2 shows that the loading indicator value is greater than the cross loading value for each variable. This shows that the value of discriminant validity has been fulfilled.

Table 2. Discriminant Value of Validity

\begin{tabular}{lcccc}
\hline & Att (X1) & SN (X2) & PBC (X3) & Int (Y) \\
\hline Attitude (X1) & 0.723 & 0.438 & 0.346 & 0.304 \\
Subjective Norm/SN (X2) & 0.438 & 0.656 & 0.129 & 0.253 \\
Perceived Behavioral Control/ PBC (X3) & 0.346 & 0.129 & 0.822 & 0.397 \\
Intention to invest in stocks/ INT (Y) & 0.304 & 0.253 & 0.397 & 0.676 \\
\hline
\end{tabular}

Reliability test is done by measuring the composite reliability value. Reliability test is a measurement of a questionnaire declared reliable if a person's answer to a question is consistent (Ghozali, 2014). Reliability test with measurements on Composite Reliability with a minimum value of 0.60 (Hair et al., 2006). The result of composite reliability shows the value obtained is at least 0.6 so that the reliability has been fulfilled.

Table 3. Value of Composite Reliability

\begin{tabular}{lc}
\hline \multicolumn{1}{c}{ Variable } & $\begin{array}{c}\text { Composite } \\
\text { Reliability }\end{array}$ \\
\hline Atittude (X1) & 0.813 \\
Subjective Norm (X2) & 0.730 \\
Percieved Behavioral Control (X3) & 0.861 \\
Intention to invest in stocks (Y) & 0.600 \\
\hline
\end{tabular}




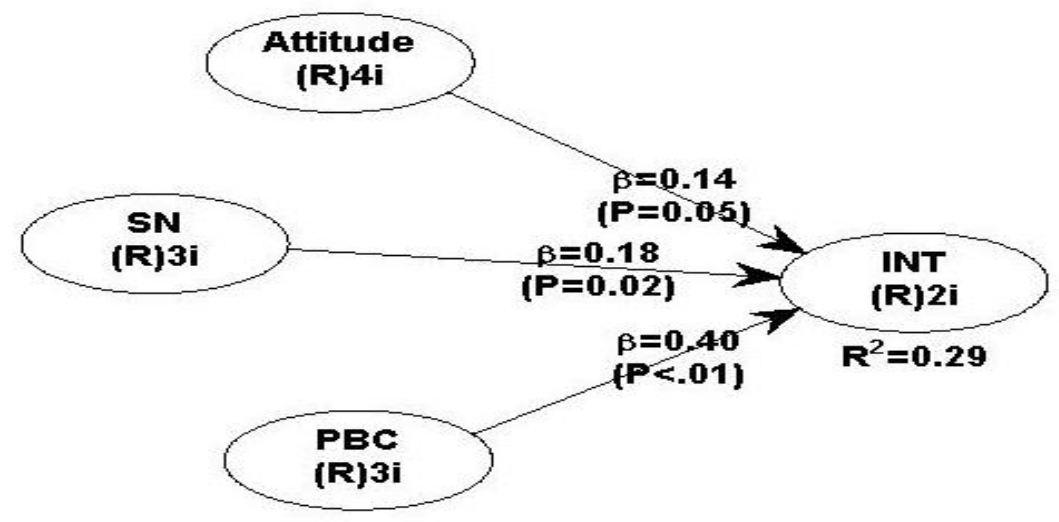

Fig. 2 Research Results Model

The rule of hypothesis testing is carried out as follows, if a $p$-value $\leq 0.01$ (alpha $1 \%$ ) is obtained then it is said to be highly significant, if a p-value $\leq 0.05$ (alpha $5 \%$ ) is obtained then it is said to be significant, if a p-value is obtained $\leq 0.10$ (alpha 10\%) is said to be weakly significant (Solimun et al., 2017). The test results show the value of Attittude (X1) on the intention to invest in stocks with a path coefficient of 0.14 and pvalue $=0.05$. The $\mathrm{p}$ value obtained is 0.05 , so it is said to be significant, so that the hypothesis $\mathrm{H} 1$ is accepted. The coefficient is positive $(0.140)$ indicating that the better the attitude, the more the intention to invest in stocks will increase. This is in line with research (Gopi and Ramayah, 2007) that attitude contributes to share purchase intentions. The test results show the value of Subjective Norms (X2) on the intention to invest in stocks with a path coefficient of 0.18 and $p$-value $=0.02$. The $p$ value obtained is 0.02 , so it is said to be significant, so that the hypothesis $\mathrm{H} 2$ is accepted. The coefficient which is positive (0.180) indicates that the better the Subjective Norms attitude, the greater the intention to invest in stocks. The results of this study support the findings (Ramayah et al., 2009) namely, there is a role of subjective norms in the intention to purchase shares investment.

Perceived Behavior Control shows the p-value $<0.01$ (alpha 1\%) can be said to be highly significant. The path coefficient on Perceived Behavior Control is 0.40 , the coefficient is positive, indicating that the better the Perceived Behavior Control, the intention to invest in stocks will increase. The results of this study are in line with the research (Cucinelli et al., 2016) which revealed that Perceived Behavior Control affects the intention to invest in stocks. Theory of Planned Behavior is used in research that focuses on investment intentions. Scholars who have financial literacy will have good knowledge. Good knowledge will form a good attitude. Knowledge about making the right investment so as not to make the wrong investment is an important part of forming a positive attitude. Attitude is a description of a person's tendency to react or respond consistently to events or phenomena (Paramita et al., 2018). Scholars assume that stock investment will provide benefits and contribute to the formation of a positive attitude. A 
good attitude will reinforce the intention to act, especially the intention to invest in stocks.

Subjective norms are influenced by various parties related to the individual concerned. Related parties become a source of reference in making decisions (Raut et al., 2018). These parties can come from colleagues, family and financial expert opinion. Positive information formed on scholars will encourage the intention to invest. Information can be obtained from the mass media, both print and electronic media. Perceived behavior control is a person's perception of the ease or difficulty of doing something (Ajzen, 1991). The convenience that is owned comes from the ability to purchase shares, the ease in obtaining stock information developments and the ability to use information technology in purchasing shares. These various conveniences affect the control of scholar behavior (Cucinelli et al., 2016). Positive behavioral control will encourage the formation of an intention to invest in stocks.

\section{CONCLUSION}

The results of data analysis and discussion that have been carried out show the influence of attitudes on intention to invest in stocks. Subjective norms influence the intention to invest in stocks. Behavioral control also shows the influence on intention to invest in stocks. These three variables indicate that attitudes, subjective norms and behavioral control have an influence on the intention to invest in shares of scholars. This study did not observe the type of stock chosen to invest. Future research is open to conducting research based on the selected stock type.

\section{REFERENCES}

Agnew, J. R. 2006. Do Behavioral Biases Vary across Individuals? Evidence from Individual Level 401(k) Data. The Journal of Financial and Quantitative Analysis, 41(4), 939-962. Retrieved from http://www.jstor.org/stable/27647280

Ajzen, I. 1991. The theory of planned behavior. Organizational Behavior and Human Decision Processes, 50(2), 179-211. https://doi.org/https://doi.org/10.1016/07495978(91)90020-T

Christanti, N., Ariany Mahastanti, L., and Ekonomika dan Bisnis Unversitas Kristen Satya Wacana, F. (2011). Faktor-Faktor Yang Dipertimbangkan Investor Dalam Melakukan Investasi. Jurnal Manajemen Teori Dan Terapan | Tahun, 4(3), 37-51.

Cucinelli, D., Gandolfi, G., and Soana, M.-G. 2016. Customer and advisor financial decisions: the theory of planned behavior perspective. International Journal of Business and Social Science, 7(12), 80-92.

Ferdinand, A. 2014. Metode Penelitian Manajemen. Semarang: Badan Penerbit Universitas Diponegoro.

Fishbein, M., and Ajzen, I. 1975. Beliefs, Attitudes, Intentions and Behaviors - Table of Contents.

Ghozali, I. 2014. Structural Equation Modeling, Metode Alternatif dengan. Partial Least Square (PLS). Semarang: Badan Penerbit Universitas Diponegoro.

Ghozali, I. 2015. Partial Least Squares: Konsep, Teknik dan Aplikasi Menggunakan Program SmartPLS 3.0 Untuk Penelitian Empiris H Imam Ghozali. In Partial Least Squares: Konsep, Teknik dan Aplikasi Menggunakan Program SmartPLS 3.0 Untuk 
Penelitian Empiris H Imam Ghozali. https://doi.org/9797043002

Ginting, A. M. 2018. Indonesian Treasury Review. Jurnal Perbendaharaan, Keuangan Negara Dan Kebijakan Publik, 3(4), 330-346.

Gopi, M., and Ramayah, T. 2007. Applicability of theory of planned behavior in predicting intention to trade online: Some evidence from a developing country. International Journal of Emerging Markets, 2(4), 348-360. https://doi.org/10.1108/17468800710824509

Hair, J. F. Jr. Black, W. C., Babin, B. J. Anderson, R. E. and Tatham, R. L. 2006. Multivariate Data Analysis 6th Edition. New Jersey: Pearson Education Inc.

Hati, S. W., and Harefa, W. S. 2019. Analisis Faktor-Faktor Yang Mempengaruhi Minat Berinvestasi Di Pasar Modal Bagi Generasi Milenial (Studi Pada Mahasiswi Jurusan Manajemen Bisnis Politeknik Negeri Batam). Journal of Business Administration, 3(2), 281-295.

Hidayat, L., Muktiadji, N., and Supriadi, Y. 2019. Pengaruh Pengetahuan Investasi Terhadap Minat Mahasiswa Berinvestasi Di Galeri Investasi Perguruan Tinggi. JAS-PT (Jurnal Analisis Sistem Pendidikan Tinggi Indonesia), 3(2), 63. https://doi.org/10.36339/jaspt.v3i2.215

Jogiyanto. 2007. Sistem Informasi Keperilakuan. Yogyakarta: Andi. Offset.

Johe, M. H., and Bhullar, N. 2016. To buy or not to buy: The roles of self-identity, attitudes, perceived behavioral control and norms in organic consumerism. Ecological Economics, 128, 99-105. https://doi.org/10.1016/j.ecolecon.2016.02.019

Junianto, D., Sabtohadi, J., Hendriani, D. 2020. Persepsi Mahasiswa Muslim terhadap Investasi Produk Syariah di Pasar Modal dalam Kajian Theory Planned Behaviour. Jurnal Shidqia Nusantara, 1(1), 51-60.

Lubis, A. I. 2010. Akuntansi Keprilakuan. Jakarta: Salemba Empat.

Munandar, A. S. 2014. Psikologi Industri dan Organisasi. Jakarta: Universitas Indonesia (UI-Press).

Paramita, R. S., Isbanah, Y., Kusumaningrum, T. M., Musdholifah, M., and Hartono, U. 2018. Young investor behavior: implementation theory of planned behavior. International Journal of Civil Engineering and Technology, 9(7), 733-746.

Paul, J., Modi, A., and Patel, J. 2016. Predicting green product consumption using theory of planned behavior and reasoned action. Journal of Retailing and Consumer Services, 29, 123-134. https://doi.org/10.1016/j.jretconser.2015.11.006

Permatasari, A., D. Y. and Abdurrahman. 2016. Faktor-Faktor Yang Mempengaruhi Niat Kewirausahaan. Jurnal Ekonomi Dan Manajemen, 13(1), 193-210.

Praharjo, A. 2020. The Effect of Service Quality on Satisfaction and Loyalty Visitors at Sengkaling Recreational Park. 10(01), 33-40.

Ramayah, T., Rouibah, K., Gopi, M., and Rangel, G. J. 2009. A decomposed theory of reasoned action to explain intention to use Internet stock trading among Malaysian investors. Computers in Human Behavior, 25(6), 1222-1230. https://doi.org/10.1016/j.chb.2009.06.007

Raut, R. K., Das, N., and Kumar, R. (2018). Extending the theory of planned behaviour: Impact of past behavioural biases on the investment decision of Indian investors. Asian Journal of Business and Accounting, 11(1), 265-292. https://doi.org/10.22452/ajba.vol11no1.9

Ruby, G. E., Ungku Zainal Abidin, U. F., Lihan, S., Jambari, N. N., and Radu, S. 2019. Predicting intention on safe food handling among adult consumers: A cross 
sectional study in Sibu district, Malaysia. Food Control, 106(June), 106696. https://doi.org/10.1016/j.foodcont.2019.06.022

Solimun, Adji A. R. Fernandes, N. 2017. Pemodelan Persamaan Struktural (SEM). Pendekatan WarpPLS. Malang: UB Press.

Sreen, N., Purbey, S., and Sadarangani, P. 2018. Impact of culture, behavior and gender on green purchase intention. Journal of Retailing and Consumer Services, 41(July 2017), 177-189. https://doi.org/10.1016/j.jretconser.2017.12.002

Sugiyono. 2014. Metode Penelitian Pendidikan Pendekatan Kuantitatif, Kualitatif, dan R\&D. Bandung: Alfabeta.

Tan, M., and Teo, T. S. H. 2000. Factors Influencing the Adoption of Internet Banking. Journal of the Association for Information Systems, 1(1), 1-44. https://doi.org/10.1016/j.elerap.2008.11.006

Tuyon, J., and Ahmad, Z. 2016. Behavioural finance perspectives on Malaysian stock market efficiency. Borsa Istanbul Review, 16(1), 43-61. https://doi.org/10.1016/j.bir.2016.01.001

Widayat. 2004. Metode Penelitian Pemasaran. Malang: UMM Press. 